\title{
IMPLEMENTING THE SOUTH AFRICAN ADDITIVE MANUFACTURING TECHNOLOGY ROADMAP - THE ROLE OF AN ADDITIVE MANUFACTURING CENTRE OF COMPETENCE ${ }^{\#}$
}

\author{
W.B. du Preez ${ }^{1 *} \&$ D.J. de Beer ${ }^{2}$ \\ ${ }^{1}$ Department of Mechanical Engineering \\ Central University of Technology, South Africa \\ wdupreez@cut.ac.za \\ ${ }^{2}$ Technology Transfer and Innovation Support Office \\ North-West University, South Africa \\ ddebeer@iclix.co.za
}

\begin{abstract}
The Rapid Product Development Association of South Africa (RAPDASA) expressed the need for a national Additive Manufacturing Roadmap. Consequentially, the South African Department of Science and Technology commissioned the development of a South African Additive Manufacturing Technology Roadmap. This was intended to guide role-players in identifying business opportunities, addressing technology gaps, focusing development programmes, and informing investment decisions that would enable local companies and industry sectors to become global leaders in selected areas of additive manufacturing. The challenge remains now for South Africa to decide on an implementation approach that will maximize the impact in the shortest possible time. This article introduces the concept of a national Additive Manufacturing Centre of Competence (AMCoC) as a primary implementation vehicle for the roadmap. The support of the current leading players in additive manufacturing in South Africa for such a centre of competence is shared and their key roles are indicated. A summary of the investments that the leading players have already made in the focus areas of the $A M C O C$ over the past two decades is given as confirmation of their commitment towards the advancement of the additive manufacturing technology. An exposition is given of how the $A M C O C$ could indeed become the primary initiative for achieving the agreed national goals on additive manufacturing. The conclusion is that investment by public and private institutions in an AMCOC would be the next step towards ensuring South Africa's continued progress in the field.
\end{abstract}

\section{OPSOMMING}

Die "Rapid Product Development Association of South Africa" (RAPDASA) het die behoefte aan ' $n$ nasionale toevoegingsvervaardigingpadkaart uitgelig. Gevolglik het die Departement van Wetenskap en Tegnologie opdrag vir die ontwikkel van so ' $n$ padkaart gegee. Hierdie was veronderstel om rolspelers te lei in die identifisering van besigheidsgeleenthede, die aanspreek van tegnologie tekortkominge, die fokus op ontwikkelingsprogramme en om beleggingsbesluite te beïnvloed wat plaaslike maatskappye en industrieë in staat sal stel om wêreldleiers op uitgekose areas van toevoegingsvervaardiging te word. Die uitdaging vir Suid-Afrika is nou op ' $n$ toepassingsbenadering wat die maksimum impak in die kortste moontlike tyd sal verseker. Hierdie artikel stel die konsep van ' $n$ nasionale Toevoegingsvervaardiging Sentrum van Bevoegdheid as ' $n$ primêre toepassing van die padkaart voor. Die ondersteuning deur die hoof rolspelers in Suid-Afrika vir so ' $\mathrm{n}$ sentrum word gedeel en hulle onderskeie rolle is aangedui. Die rolspelers se toewyding word gestaaf aan die hand van hul beleggings in die fokus areas van die Sentrum oor die laaste twee dekades. ' $n$ Uiteensetting word verskaf van hoe die Sentrum inderdaad die hoof inisiatief vir die behaal van die ooreengekome nasionale doelstellings kan word. Die gevolgtrekking is dat belegging deur

\footnotetext{
\# This article is an extension of a paper presented at the $15^{\text {th }}$ Annual International RAPDASA conference held in Stellenbosch, South Africa in November 2014

Corresponding author
} 
die publieke en privaat instansies in so ' $\mathrm{n}$ sentrum die volgende stap tot die versekering van Suid-Afrika se voortgesette vordering in veld is.

\section{INTRODUCTION}

Additive Manufacturing $(A M)$ is often described as the next chapter in the industrial revolution. In Europe, AM has recently been recognised as a key emerging technology. As a result, efforts to drive the technology into manufacturing applications have increased. In its 2014 Strategic Research Agenda for AM, the European AM Platform [1] identifies two distinct markets in which $A M$ has flourished over the last few years: the industrial or production market, which includes medical (orthopaedic implants), dental, aerospace, automotive, and power generation; and the consumer market, which includes home accessories, fashion, and entertainment. In a report published in May 2013, the McKinsey Global Institute [2] included AM as one of the current disruptive technologies.

\section{MAJOR INTERNATIONAL ADDITIVE MANUFACTURING INITIATIVES}

Internationally, players are networked and efforts have been coordinated to achieve maximum impact. Many governments around the world have taken the lead in this by investing in national initiatives to promote research in $A M$ and to educate industry about the potential it offers. Wohlers [3] has reported that successful programs are being conducted in the US, Europe, and Asia for technology and human capital development in AM.

- In Europe, regional $A M$-focused funding initiatives and project-based research has been established. This is led by the European AM Platform. [1]

- Inter-departmental cooperation in the US government has led to the visionary 'America Makes', also known as the National Additive Manufacturing Innovation Institute (NAMII). The US government's initial investment of US\$30 million rose in March 2014 to a total public funding of US\$50 million [3].

- There are two research networks for $A M$ in Germany: the Fraunhofer Additive Manufacturing Alliance; and the Direct Manufacturing Research Centre (DMRC), which is located at the University of Paderborn [4]. The Fraunhofer Additive Manufacturing Alliance is reputedly the largest inter-disciplinary European alliance of competence for high-speed processes that enable the manufacture of products from metal, plastic, ceramic, and other powders. They have a focus on enhancing the performance and competitiveness of small- and medium-sized enterprises. The DMRC consists of national and international players, and has the objective of promoting the development of $A M$ processes and systems and to make $A M$ a standard production process.

- $\quad$ The RMIT Advanced Manufacturing Precinct in Melbourne, Australia, is funded by more than US\$20 million in investment from the Australian government [3]. With advanced manufacturing accounting for half of Victoria's manufacturing output, this Advanced Manufacturing Precinct is intended to help Victorian companies develop new, sustainable products with state-of-the-art equipment.

- In Singapore, the Nanyang Technological University's Additive Manufacturing Centre was established with the goal of bringing together disparate AM-related research efforts from across several organisations and universities in Singapore, and to become a national centre of excellence in AM. In 2013, this centre received investment of over US\$30 million from Singapore's Economic Development Board [3].

- The China 3D Printing Technology Industry Alliance forms part of the Chinese government's plans to support $A M$ and to develop a medium- and long-term strategy for AM [4]. China has also announced the establishment of a 3D printing industrial park, which will include a large rapid prototyping and manufacturing centre.

- In the drive towards standardisation and certification, the ASTM F42, BSI, and ISO have commissioned working groups on standards development [1]. The ASTM and ISO have 
taken a ground-breaking approach by deciding to collaborate in the development of AM standards.

\section{SOUTH AFRICAN ADDITIVE MANUFACTURING COLLABORATION}

Given this exciting international environment, South Africa has a rare opportunity to capitalise on its strong and internationally-recognised position in the AM field as part of its Advanced Manufacturing drive.

Through the Rapid Product Development Association of South Africa (RAPDASA), which is a voluntary association, the key players from academia, research and development (R\&D) institutions, and industry have been cooperating and collaborating at various levels since 2000. The annual RAPDASA conference has grown into the primary annual opportunity for participants from the $A M$ community, both locally and internationally, to share their achievements and experiences. However, while RAPDASA has been beneficial for the country, it is only a voluntary association, and so has limited influence and impact in the South African economy. This makes it opportune now to consider a more structured and sustainable national collaborative initiative for South Africa.

\section{THE SOUTH AFRICAN ADDITIVE MANUFACTURING TECHNOLOGY ROADMAP}

During their Annual General Meeting in 2012, RAPDASA expressed the need for a national Additive Manufacturing Roadmap. In response to this resolution, the South African Department of Science and Technology commissioned the development of a South African Additive Manufacturing Technology Roadmap in 2013. Such a technology development route was intended to guide South African players in identifying economic opportunities, addressing technology gaps, focusing development programmes, and informing investment decisions. This roadmap was intended to enable local companies and industry sectors to become global leaders in selected areas of $A M$. The recommendations of the AM Technology Roadmap regarding focus areas for future interventions in the field of $A M$ are presented in Figure 1.

\begin{tabular}{|c|c|}
\hline $\begin{array}{l}\text { - Use of AM for production of medical and dental implants } \\
\text { - Use of AM for production of medical devices } \\
\text { - Production of parts for the Aerospace and military markets based on current } \\
\text { customers and collaboration agreements with OEM's }\end{array}$ & $\begin{array}{l}\text { Qualified AM } \\
\text { parts for medical } \\
\text { and aerospace }\end{array}$ \\
\hline $\begin{array}{l}\text { - Improve efficiency of traditional manufacturing sectors through tooling } \\
\text { development and improved product development cycles } \\
\text { - Refurbishment of previously unserviceable parts for the local industry by } \\
\text { means of powder deposition technology }\end{array}$ & $\begin{array}{l}\text { AM for Impact in } \\
\text { traditional } \\
\text { manufacturing } \\
\text { sectors }\end{array}$ \\
\hline $\begin{array}{l}\text { - Development of Additive Manufacturing systems } \\
\text { - Development of Materials for AM } \\
\text { - Development of new AM technologies }\end{array}$ & $\begin{array}{l}\text { New AM } \\
\text { Materials and } \\
\text { technologies }\end{array}$ \\
\hline $\begin{array}{l}\text { - Development of an AM based SMME industry in South Africa based on/ } \\
\text { strenghtened by Additive Manufacturing technology } \\
\text { - Prosthetics, Dental, Hearing aids, Jewelry, Creative Arts }\end{array}$ & $\begin{array}{c}\text { SMME } \\
\text { development }\end{array}$ \\
\hline
\end{tabular}

Figure 1: Recommendations of the South African AM Technology Roadmap 
Taking note of the international trends and initiatives, as well as the above-mentioned recommendations, an Additive Manufacturing Centre of Competence (AMCoC) was proposed as the primary implementation vehicle of the South African Additive Manufacturing Technology Roadmap.

The Centre of Competence $(\mathrm{CoC})$ model is a well-established vehicle for achieving the desired stronger, focused national programmes that would result in increased economic impact. It was developed by the South African Department of Science and Technology (DST). In their formal document describing the CoC model, the DST published the following characteristics of a $\mathrm{CoC}[5]$ :

Intention: To provide a formal and, as far as possible, contractually secure physical or virtual platform upon which to establish collaborative technology development partnerships between government, industry, higher education, and research institutions, with the explicit aim of technology commercialisation.

Participation: Ideally, the participants in a CoC should include South African universities, research councils, and South African-based companies that have a research and technology development strategy or vision, are open to working with like-minded companies, and are prepared to collaborate with universities and research councils.

\section{MISSION OF THE ADDITIVE MANUFACTURING CENTRE OF COMPETENCE}

As the primary implementation vehicle of the South African Additive Manufacturing Technology Roadmap, the South African AMCOC maximises the potential for success and impact by aligning existing and future $A M$ research and development activities. The AMCOC has the mandate to develop, industrialise, and commercialise the technologies needed to grow a vibrant and internationally-competitive manufacturing industry in South Africa.

\section{THE ADDITIVE MANUFACTURING CENTRE OF COMPETENCE FRAMEWORK}

The proposed activities and focus of the $A M C O C$ are captured in Figure 2: 


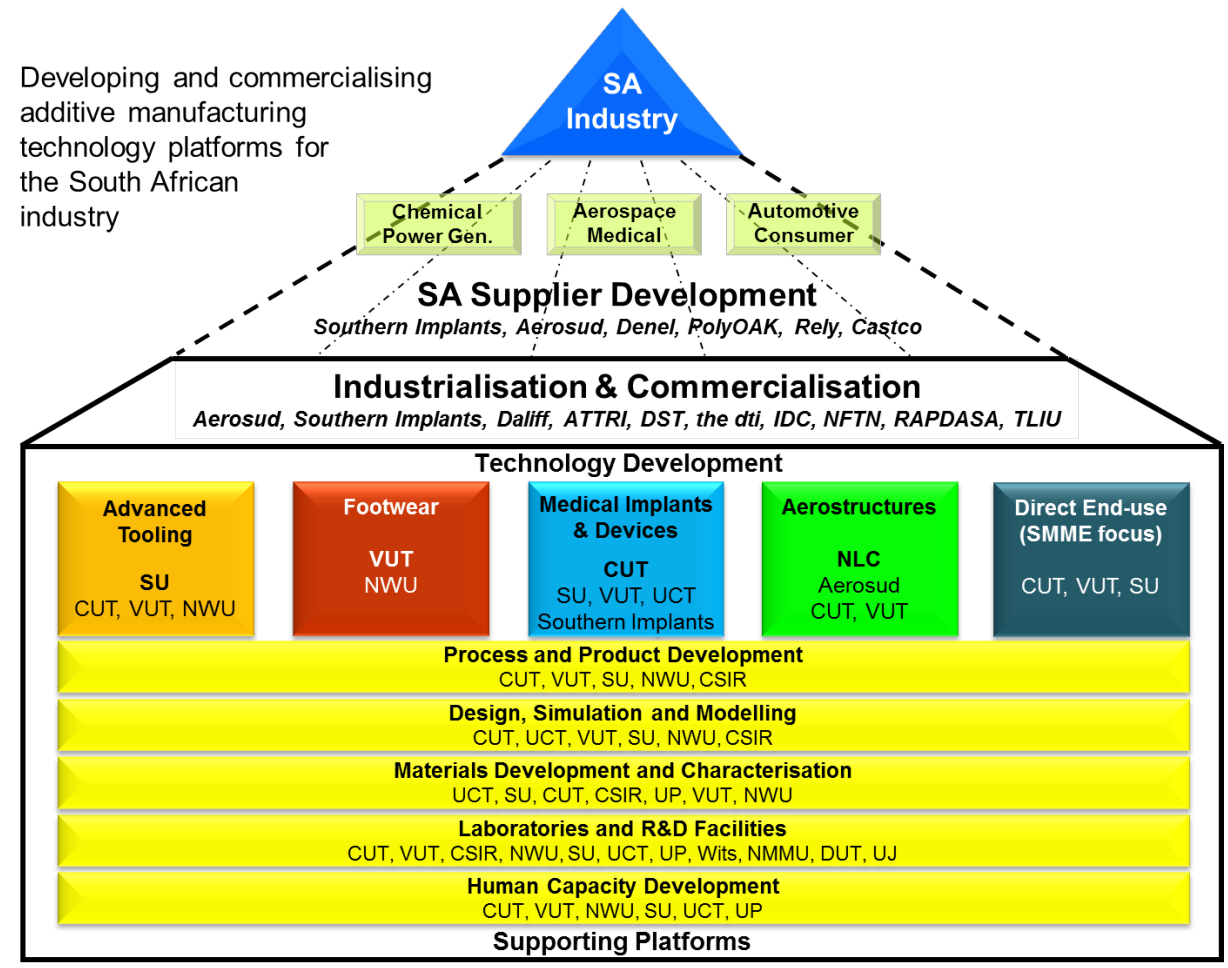

Figure 2: The activities and collaborators of the South African Additive Manufacturing Centre of Competence

\section{Key to Figure 2:}

DST: $\quad$ Department of Science and Technology

the dti: $\quad$ Department of Trade and Industry

NFTN: National Foundry Technology Network

RAPDASA: $\quad$ Rapid Product Development Association of South Africa

TLIU: $\quad$ Technology Localisation Implementation Unit

SU: $\quad$ Stellenbosch University

CUT: $\quad$ Central University of Technology, Free State

VUT: $\quad$ Vaal University of Technology

NWU: $\quad$ North-West University

UCT: $\quad$ University of Cape Town

NLC: $\quad$ National Laser Centre

CSIR: $\quad$ Council for Scientific and Industrial Research

UP: $\quad$ University of Pretoria

Wits: $\quad$ University of the Witwatersrand

NMMU: $\quad$ Nelson Mandela Metropolitan University

DUT: $\quad$ Durban University of Technology

UJ: $\quad$ University of Johannesburg

As indicated in Figure 2, the overall intention of the $A M C O C$ is to support the establishment of a vibrant, growing, and internationally-competitive $A M$ supplier sector. This supplier industry would serve end-use markets, such as chemical, power generation, aerospace, medical, automotive, and consumer goods. For this to be realised, South African suppliers to these industries have to be established and supported with the technologies that would ensure their global competitiveness. Based on the recommendations of the South African Additive Manufacturing Technology Roadmap, the technology platforms that have to be developed, industrialised, and commercialised for this purpose were selected and are shown as the multi-coloured blocks in Figure 2. Apart from the technology area (e.g., 
Advanced Tooling, Footwear, Medical Implants \& Devices, Aerostructures), the key players in the technology focus area are also indicated (e.g., SU, CUT, VUT, NWU). In each block, the leading player is indicated by its acronym in bold text. The supporting platforms in the lower part of the diagram are underpinning capabilities that are considered essential for all of the technology focus areas; therefore, they span the whole width of the diagram. The various institutions contributing to these platforms are also shown.

\section{THE ADDITIVE MANUFACTURING CENTRE OF COMPETENCE VALUE PROPOSITION}

The proposed $\mathrm{CoC}$ engages the collaboration of a multi-disciplinary South African team with a very powerful, world-class set of integrated capabilities and expertise. This gives South Africa the best possible chance of having a significant impact in the rapidly-growing field of $A M$, which is applied in challenging industries such as medical, aerospace, power generation, automotive, and chemical processing.

Progress over several years has led to South Africa being in a very competitive position internationally, as it participates in the full value chain, from materials development to qualified AM parts. Significant research capacity has been built up in Metals-based Additive Manufacturing (MAM), particularly using titanium alloy powder, through a focused approach by several participating institutions. If the local Polymer-based Additive Manufacturing (PAM) activities are reviewed, it can be shown that, historically, participating institutions performed equally well internationally. Therefore the $A M C O C$ will include both MAM and PAM, and support research activities in both categories. As a strategic initiative, the NorthWest University in Potchefstroom, South Africa, together with other applicable role-players (e.g., SASOL, Polifin, CSIR, SU), will investigate the local production of PAM materials. The local development of consumable polymer materials also creates a strategic opportunity for the development of local PAM platforms. The latter, which has started at the Vaal University of Technology (VUT), offers a significant opportunity for more institutions to participate, since many of the existing patents covering the current international original equipment manufacturer (OEM) base have expired or are on the way to expiring.

Experience gained in the local development of entry-level $A M$ platforms has paved the way for the development of more specific higher-end technologies. A crucial part of the AMCoC focus will be the development of local expertise that uses the current research community, especially through student involvement following on from a focused R\&D and human resource development, and starting at internship level to gain experience and receive training. Experience has also shown that there is ample space for information and communication technology (ICT) participation, as another cross-cutting human resource development and R\&D focus.

The institutions collaborating in the $\mathrm{AMCOC}$ offer the following key competences:

- $\quad$ Central University of Technology (CUT): The most versatile range of AM machines in the country, and in-depth expertise in the operational and research aspects of the technology, supported by physics, materials science, and mechanical engineering competence, as well as proven $\mathrm{CoC}$ management capability.

- $\quad$ Stellenbosch University (SU): Selective Laser Melting (SLM) of Ti alloys, tooling, and stainless steels with a Concept Laser M2 system, expertise in the operational and research aspects of the technology, and fracture mechanics and materials science competence. Extensive experience in 3D printing (binder jetting) in manufacturing, medical, and architectural applications.

- National Laser Centre (NLC): Powder-blown AM with an Optomec 850R machine, as well as other high-power laser and beam delivery systems. In-depth expertise in AM machine development, laser technology, and materials science competence in collaboration with CSIR Materials Science and Manufacturing. Strong focus on process development for aerospace components and $\mathrm{AM}$ for refurbishment applications.

- Vaal University of Technology (VUT): An extensive range of polymer AM machines, focusing on the support of specific industry clusters such as the South African shoe and 
leatherwear cluster and the foundry sector, in addition to well-equipped metallurgical laboratories with emerging capabilities in the metallurgy of titanium alloys, focusing on the metallurgy of SLM parts through their on-going collaboration with CUT. VUT also owns the Idea 2 Product Labs ${ }^{\circledR}$, a local AM replacement of the MIT FabLab concept (founded by De Beer and Jooste), which aims to deliver AM education and innovation support to school learners, students, and the general public.

- $\quad$ North-West University (NWU): An internationally-recognised expert in AM, with established competence in occupational health and safety and a recent focus on the processing of powders. Further expertise available through the Centre for Advanced Manufacturing, which operates as a Department of Trade and Industry Centre of Excellence in Advanced Manufacturing, and also participates nationally in the training of tooling engineers. Vast expertise in materials science (including polymers and platinum group metal (PGM) materials) to support new strategic initiatives.

- Aerosud: World-class design and manufacturing capabilities in the commercial, noncommercial, and military aerospace markets. Dedicated R\&D activities in the field of $A M$ and world-leading activities in the field of high-speed, large-volume Additive Manufacturing. Current supplier of $A M$ end-use parts to aerospace industry.

Apart from the above-mentioned synergy, the individual collaborating institutions have established track records of investment in the facilities and expertise development required to participate in the $A M C O C$. A recent survey confirmed that these entities have, since the middle 1990s, invested more than ZAR155 million in AM machines, and have executed AM projects in excess of ZAR200 million.

Under the leadership of these universities and collaborating companies, the AMCoC delivers the following national benefits:

- $\quad$ Qualified $A M$ processes and post-processing techniques that could be transferred to new and existing firms using $A M$ technology, thereby improving their ability to innovate and their global competitiveness.

- Development of an internationally-competitive position in metal-based and polymerbased $A M$ activities and processing value-chain, to empower the local design and fabrication of customised medical and consumer goods, and to enter the automotive and aerospace industries through batch production of complex designs and assemblies.

- A healthy, self-sustaining $A M$ industry sector that serves a number of end-user industries such as medical, dental, aerospace, jewellery, casting and foundry, consumer products, automotive, and architecture; this also enables job and wealth creation and contributes to the South African gross domestic product (GDP).

- $\quad$ Delivery by participating universities of students who are qualified in $A M$ and suited for employment in knowledge-based jobs.

- Proven 'design for $A M$ ' understanding, ability, and capacity in both academia and industry, which leads to excellent $A M$-manufactured products that are used locally and internationally across various industries.

- Sustained delivery of research and development outputs, such as postgraduate qualifications, journal articles, conference papers, patents, technology demonstrators, and spin-out companies.

- A national identity with which stakeholders and the general public can associate, and which could promote AM awareness-creation in South Africa.

\section{CONCLUSION}

Following the results achieved from a unique development approach over the past two decades, it is clear that the different initiatives taken to date have enabled South Africa to become an international contender in the AM field. Although a late adopter of Rapid Prototyping/AM technologies, various achievements have been recognised internationally and lessons learned that could be transferred to other countries, not excluding the initial international leaders. 
Being a founding member of the Global Alliance of Rapid Prototyping Associations (GARPA) opened the door to international participation, even though the initial affiliate membership was under the auspices of the National Product Development Centre (NPDC). This led to the formation of RAPDASA, which created a community of practice and a special form of professional or industry association to promote AM in South Africa. RAPDASA, as an official representative group of $A M$ in South Africa, and supported by its international status, opened the doors to the first official government support that led, among other things, to the South African AM Roadmap process, as well as a first round of consortium research funding proposals to the DST. In addition, the recent uptake of $A M$ technologies in the Department of Trade and Industry's Industrial Policy Action Plan (IPAP Six) serves as further recognition by government.

Following from the recent successes, it is the view of the authors that the proposed AMCoC should be the next logical step towards achieving similar goals to those indicated in the major international success models. The authors also believe that the AMCoC could go a long way towards creating the kind of R\&D environment that is most conducive for the maximum impact of AM in the South African economy. Given South Africa's recognition as a relevant player in the global $A M$ community, enhanced further by its potentially competitive position through the future local production of titanium and polymer powder, the establishment of an $A M C O C$ could impact very positively on creating an economic growth opportunity through developing and transferring these advanced manufacturing technologies and their applications to the local industry.

\section{REFERENCES}

[1] AM Platform. 2014. Additive manufacturing: Strategic research agenda. Retrieved from http://www.rmplatform.com/linkdoc/AM\%20SRA\%20Consultation\%20Document.pdf

[2] McKinsey Global Institute. 2013. Disruptive technologies: Advances that will transform life, business, and the global economy, McKinsey \& Company. Retrieved from http://www.mckinsey.com/insights/business_technology/disruptive_technologies

[3] Wohlers Associates. 2014. Preparation of a South African additive manufacturing technology implementation roadmap, Wohlers Associates, Inc., Fort Collins USA. Input to roadmap project team.

[4] Stahl, H. 2013. 3D Printing - Risks and opportunities, Öko-Institut e.V.. Darmstadt. Retrieved from http://www.oeko.de/en/publications/p-details/3d-printing-risks-and-opportunities/

[5] DST. 2010. Framework for centres of competence (CoCs) in South Africa. Department of Science and Technology. 